in the name of the foreign delegates. The proceedings concluded with a speech by M. Mario Roustan, the Minister of Education.

Sir Arthur Hill, after referring to some of the distinguished botanists who had made the name of the Museum famous throughout the world, concluded a noteworthy speech, which brought the whole company to their feet, with the following words :

"Tous ceux-ci-et beaucoup d'autres-ont fait rayonner leur lumière sur le monde entier, au travers de ce Temple Renommé, le Musée National d'Histoire Naturelle.

"M. le Président, permettez à un botaniste de vous rappeler la fameuse parole de votre grand philosophe Pascal : L'homme fut perdu et trouvé dans un Jardin. Dans le premier jardin, le Jardin d'Eden, l'homme ouvrit la porte de la Science en mangeant le fruit de l'arbre de la connaissance du Bien et du. Mal. Pouvons nous exprimer l'espoir que, nonseulement en France, mais au travers du monde entier, malgré les temps si troublés que nous traversons, unis dans un même idéal de tolérance et d'harmonie, les chercheurs de la Vérité verront leurs efforts récompensés par la découverte de cet autre arbre-'L'Arbre de Vie', dont les feuilles nous assureront la Paix eternelle, parmi les Nations?

"M. le Président, je prie mes collègues Délégués de se joindre à moi, et, debouts, de rendre hommage à la mémoire de ceux qui ont fait le nom de ce Musée si grand, et d'offrir avec moi nos meilleurs vœux pour la continuité de la prosperité et la gloire du Musée National d'Histoire Naturelle."

In the evening there was an official banquet attended by some seven hundred guests, and the Earl of Crawford spoke on behalf of the British delegates.

Another event of the week was the opening of the Grande Galerie de Botanique du Jardin des Plantes, the erection of which was assisted by a grant from the Rockefeller Foundation. This magnificent new building consists chiefly of the herbarium, which is one of the largest in the world. The building is fireproof and the herbarium cabinets are constructed of metal. There is very limited table space, and most of the research work is carried out in the adjoining private rooms and laboratories, several of which have been set aside for the use of visitors. There is, moreover, particularly good accommodation for workers on the lower cryptogams, some seven rooms being set aside for algology, and an equal or larger number for mycology. Including more or less loosely attached workers, there is a large staff, but the new herbarium laboratories are also used by university students in connexion with research for degree theses.

Visits were paid to the Château of Chantilly and various museums, as well as to the zoological parks at Clères and Vincennes and the experimental grounds and laboratories of M. Vilmorin. The celebrations in Paris were very pleasantly brought to a close by a garden party at the Elysée, when the President of the Republic and Mme. Lebrun received the delegates.

At the end of the festivities an excursion was made to Mont Saint-Michel, Saint-Malo and Dinard, and at Dinard the new museum and aquarium, recently completed, was formally opened in the presence of a large number of the delegates.

Thanks to M. Lemoine, the director of the Museum, to Dr. Jeannel, who was acting as secretary, and his assistants, the arrangements for the celebrations were admirably carried out.
A very interesting exhibition of portraits of all the distinguished botanists, zoologists and others connected with the Museum, together with a fine collection of old prints and pictures and many other objects connected with the history of the Museum, had been arranged in the Exhibition Hall of the recently completed herbarium and botanical laboratories referred to above.

Academies, universities and scientific institutions from all over the world sent delegates to the celebrations. The following institutions, among others, of Great Britain, were represented : Royal Society (Earl of Crawford and Balcarres and Dr. C. Tate Regan); British Museum, Natural History (Earl of Crawford and Balcarres, Dr. C. Tate Regan and Mr. J. Ramsbottom); Royal Botanic Gardens, Kew (Sir Arthur Hill and Mr. A. D. Cotton); British Association (Mr. J. Ramsbottom); and the Linnean Society of London (Mr. J. Ramsbottom and Prof. G. D. Hale Carpenter).

\section{Biological Distribution of Molybdenum}

DROF. H. TER MEULEN, of Delft, continues his studies on the distribution of molybdenum in the organic world, with the help of Miss H. J. Ravenswaay (K. Akad. Wet. Amsterdam, Proc., 38, i ; 1935 ; see also Nature, 130, 966 ; 1932). Finding in various samples of Dutch East Indian tobacco no less than $0.5-0.7 \mathrm{mgm}$. of molybdenum per $\mathrm{kgm}$., he went on to determine the molybdenum content of the soil in a number of tobacco plantations. In some the amount was small, $0 \cdot 01-0.07 \mathrm{mgm}$. per $\mathrm{kgm}$. ; in others it was ten times as much, $0 \cdot 12-0 \cdot 3$ mgm. ; and the latter were always the best plantations, growing the best tobacco.

Next, Prof. Ter Meulen extended some former studies of the seasonal variation of molybdenum in leaves; he finds in about a dozen different trees that the amount per kilogram, or per 1,000 leaves, either remains constant or sometimes increases considerably, from the young leaves of spring until the autumn leaves are about to fall. In other words, the molybdenum does not migrate from the old leaves to the other tissues of the plants, but merely returns with the fallen leaves to the soil. The horse-chestnut is an exception; here the amount of molybdenum in the leaves decreases in September and still more in October. But the horse-chestnuts themselves contain this element in considerable amount, and have, in all probability, withdrawn it from the leaves.

A third interesting point is a comparison of the molybdenum content in the brown and green varieties of Prunus, hazel and beech. Leaves were plucked on the same day, and the molybdenum estimated in $\mathrm{mgm}$. per $\mathrm{kgm}$. of moisture-free material. The curious and striking result was that in all three species the brown-leaved varieties were found to contain about twice as much molybdenum in their foliage as the green ones.

Still more recently, Prof. Ter Meulen has studied the molybdenum content of human teeth, sound and carious, and finds the sound teeth to be very much richer in molybdenum than the unsound. In all these cases it seems natural to suppose that the molybdenum is playing its part as a catalyst, and as such it would seem to be of widespread use and importance. 